\title{
Civil service reforms in Hong Kong and Thailand: similar goals, different paths
}

\author{
Ahmed Shafiqul Huque \\ McMaster University, Hamilton, Canada, and \\ Patamawadee Jongruck \\ Chiang Mai University, Chiang Mai, Thailand
}

Civil service reforms in Hong Kong and Thailand

Received 11 March 2020

Revised 31 March 2020

Accepted 4 June 2020

\begin{abstract}
Purpose - The purpose of this paper is to examine the strategies of civil service reforms in Hong Kong and Thailand. It seeks to identify the drivers of reforms in the two cases and explain the divergence in processes that were intended to achieve similar ends.

Design/methodology/approach - This paper adopts a case study approach along with a thorough review of the literature. It is based on secondary materials, including academic studies, government publications and websites, and media reports. It compares approaches, strategies and outcomes of civil service reforms in Hong Kong and Thailand.

Findings - Civil service reforms in Hong Kong focused on improving management through the implementation of New Public Management (NPM) principles, while governance values were prominent in civil service reforms in Thailand.

Originality/value - This paper compares civil service reforms in two dissimilar Asian cases. It highlights the impact of global trends on traditional bureaucratic organizations and reform strategies, and recognizes the impacts of traditions, culture and capacity on civil service reforms.
\end{abstract}

Keywords Civil service reforms, New Public Management, Governance, Hong Kong, Thailand

Paper type Case study

\section{Introduction}

The traditional approach to public administration came under criticism for its mechanical and process-based orientation that resulted in continuous growth in the size of the bureaucracy, along with a decline in productivity. There were criticisms over escalating costs, and the lack of accountability and transparency affected the quality of services. Rhodes noted that traditional public administration "was seen as the problem, not the solution" (2016, p. 639). These circumstances ushered in significant changes in the form of New Public Management (NPM). The objectives were to reduce expenditure, improve service delivery, and incorporate flexibility to enhance performance in public sector organizations that represented a clear shift from traditional public administration; consequently, far greater attention focused on the achievement of results and personal responsibility of managers (Hughes, 2012). The pressure to introduce changes in their civil services also influenced Hong Kong and Thailand.

While civil service reforms generally aim at changes for improvements, this paper argues that reforms are also influenced by societal values, ideology and political preferences of

(C) Ahmed Shafiqul Huque and Patamawadee Jongruck. Published in Public Administration and Policy. Published by Emerald Publishing Limited. This article is published under the Creative Commons Attribution (CC BY 4.0) license. Anyone may reproduce, distribute, translate and create derivative works of this article (for both commercial and non-commercial purposes), subject to full attribution to the original publication and authors. The full terms of this license may be seen at http://creativecommons. org/licences/by/4.0/legalcode

\section{HKPAA}

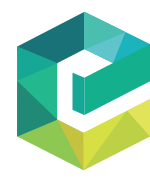

Public Administration and Policy Vol. 23 No. 2,2020 pp. $111-123$ Publishing Limited DOI 10.1108/PAP-03-2020-0015 
PAP

23,2

112

regimes. Also, the nature of the state, strength of the bureaucracy and the capacity of governments determine the direction of reforms. This paper examines civil service reforms in the Hong Kong Special Administrative Region of the People's Republic of China and the Kingdom of Thailand. The influence of NPM was prominent more in rhetoric than substance in most Asian countries. However, Cheung (2011) noted that NPM faced a legitimacy crisis as countries sought to adopt alternative development models. This paper argues that civil service reforms in Hong Kong were influenced by NPM principles and oriented toward efficient management with minimal attention to political and social implications. Thailand, too, intended to achieve efficiency, but the values of democracy and governance emerged as important elements in Thai civil service reforms.

This paper adopts a case study approach because it is appropriate for closely examining data within a specific context. It undertakes a review of the literature to identify the nature of civil service reforms and the causes of divergence in strategies adopted by Hong Kong and Thailand. The discussion is based on secondary materials obtained from academic studies, information from the two governments, relevant websites, and media reports. These sources provide information on the history, tradition, and developments of civil services as well as substance and trends of reforms. The arguments are established by comparing approaches, strategies and outcomes of civil service reforms in Hong Kong and Thailand. The two units share a similar characteristic of a robust bureaucratic structure. Another point of commonality is that the reforms were motivated by global trends and pressures. However, Hong Kong and Thailand are strikingly dissimilar in all other respects. They were selected to demonstrate that there are common objectives across countries, and they influence the design of reforms. At the same time, the two cases help strengthen the argument that despite designing reforms with similar goals, additional factors such as traditional, societal and political forces result in the adoption of different strategies.

\section{Civil service reforms}

The role of civil service entails several complex and interrelated activities that are coordinated to ensure good governance through a network of transparent, accountable and efficient arrangements. This is critical because public administration "must provide a framework of organizations as well as a body of capable personnel to enable the government and the citizens" to achieve the objectives of the state, and it "is obvious that more emphasis is placed on the personnel than the structures, because the former determines, to a large extent, the outcome of the latter" (Huque, 1990, p. 55). Thus, civil service reform is an important, yet challenging task for governments in every country. It generally includes reforms in areas such as remuneration, human resources, downsizing and operational efficiencies; however, it has received inadequate attention in comparison to other types of reforms in the public sector (Repucci, 2014).

Powerful countries, international agencies, and financial institutions have a strong influence on reform goals and processes. The wave of NPM reforms initiated in the developed world in the late 1980s influenced civil service reforms in many countries. NPM has two main dimensions: on the one hand, it aims to improve the quality of public service delivery by introducing the concept of managerialism; on the other hand, it emphasizes the need to downsize the public sector (de Vries and Nemec, 2013). The experiences of NPM reforms in the 1990s and 2000s, especially from some developing countries, illustrated its limitations and unanticipated consequences. Moreover, concerns about social inclusion, poverty reduction, and sound government underlined the need for an alternative reform ideology (Brinkerhoff and Brinkerhoff, 2015).

Good governance is another prominent factor that influenced civil service reforms in developing countries. Promoted by international donors, good governance is illustrated by several characteristics: participation; rule of law; transparency; responsiveness; consensus- 
orientation; equity; effectiveness and efficiency; accountability; and strategic vision (UNDP, 1997). Good governance and human development are intimately related, and one cannot be sustained without the other (UNDP, 1997). Although it rapidly became popular, Grindle (2017) pointed out that good governance is merely a normative concept that requires many resources as well as the capability of governments to achieve those 'good' qualities but with little understanding of how to get there. Moreover, it encourages a one size fits all approach to governance, without taking into consideration the contexts of specific countries. Civil service reform is indeed an ongoing process - one which needs to be tailored to each country's needs to find the most suitable approach for their context.

\section{Hong Kong and Thailand: contexts and contrasts}

Hong Kong has a land area of 1,106 square kilometres, with a population of approximately 7 million. Thailand, on the other hand, has a land mass of 513,120 square kilometres and a population of roughly 69 million. While Hong Kong is administered centrally with some input from 18 local districts, Thailand has several levels of administration at central, provincial and local government levels. The two cases of Hong Kong and Thailand have different traditions of managing the civil service. The divergence is understandable between an ancient kingdom and a former colony of Great Britain that was eventually designated as a Special Administrative Region of China. Although their reform strategies and trajectories differed due to culture, history, traditions and practices, the goals in both cases were similar.

In Hong Kong, a simple structure of government was facilitated by the absence of strong political forces and a high degree of acquiescence by administrative officials in implementing reforms (Lee and Huque, 1996). The government adopted the strategy as it sought to administer Hong Kong as a colony, and the Governor (retitled as Chief Executive in 1997) exercised complete control over the territory. Many of the arrangements established before the handover to China continued after the termination of colonial rule, and the same administrative culture persisted.

The civil service is the largest employer in Hong Kong, with a total strength of approximately 174,900, amounting to about 4.4 percent of the Hong Kong workforce (Hong Kong Government, 2018). "It supports the government in formulating, explaining and implementing policies, conducting administrative affairs, delivering public services, and undertaking law enforcement and regulatory functions" (Hong Kong Government, 2018). In the absence of a strong representative mode of governing, civil servants leading 13 policy bureaus and 56 departments enjoy considerable power. Initially, the Central Policy Unit was expected to undertake research, analyse policy issues, and recommend government action. Later, the emphasis shifted to "the government's commitment to improve services to the community and to enhance openness and accountability by formulating, securing support for, and overseeing, the implementation of public sector reform” (Hong Kong Government, 1996, p. 19).

In contrast, Thailand was never colonized, and the establishment of western-style ministries in 1892 was a strategy to avoid colonization (Brown, 1992). A system based on the merit principle was introduced with the promulgation of the first Civil Service Act in 1928 (Bowornwathana and Poocharoen, 2005). Thailand was described as a 'bureaucratic polity' in which ministers were more responsive to the interests of their bureaucratic subordinates than the needs and demands of other groups (Riggs, 1966). Tjiptoherijanto (2018) noted that the power of civil servants stemmed from the reliance of the military on the bureaucratic elite and described them as permanent members of the political class. Moreover, the bureaucracy retained control over the polity as well as administration because coalition governments were generally weak and indecisive (Bowornwathana, 2001).

The number of civil servants in Thailand - excluding the Ministry of Defence - was approximately 2 million in 2018. This is equivalent to 3.15 percent of the country's population
Civil service reforms in Hong Kong and Thailand 
PAP

23,2

114

and 5.45 percent of its workforce (OCSC, 2019a). The majority of civil servants work in the central and provincial administration and constitute 81.89 percent of the officials. The Office of the Public Sector Development Commission (OPDC) found that the Thai public sector was too large and complex, and its management was ineffective, inefficient and unresponsive to citizen needs. The large number of officials was a challenge in managing the bureaucracy (Worragi, 2003). Bowornwathana (2001, p. 298) described the Thai bureaucracy as "wasteful, ineffective, non-responsive, unfair, not accountable, slow, corrupt and unethical". Therefore, there were pressures from internal and external sources for introducing reforms in the civil service of Thailand.

\section{Civil service reforms in Hong Kong}

The nature and philosophy of the civil service under colonial rule are markedly different from those of independent states. Hong Kong was administered through a simple and centralized system of administration. This was facilitated by the fact that the public in Hong Kong had accepted such a system of rule and remained apathetic to public affairs under British rule. The economy performed well to produce a gradual growth of affluence. With no public demand for change, the government was satisfied with making minor adjustments to existing administrative agencies and practices, and the civil service system remained unchanged for a long time. The government aimed to ensure control and political stability as well as the robustness of the economy. The social aspect of public administration was neglected as Hong Kong progressed on the road toward economic prosperity.

A major civil unrest in Hong Kong in 1967 and problems with corruption sparked demands for reforms in the civil service. An investigation into the public discontent indicated that there was great dissatisfaction with the arrangements for social welfare and employment, and significant improvements had to be brought about in those fields (England and Rear, 1981, p. 17). Following the unrest that took place in the wake of the Cultural Revolution in China, the government introduced "a number of piecemeal structural reforms" (Scott, 1984, p. 6). A key step was opening the space for citizens' participation in public affairs and preventing the possibility of abuse of power, maladministration, and overstepping of jurisdictions by public servants (Huque et al., 1998).

The Independent Commission Against Corruption was established in 1974 to detect and investigate corruption (Scott and Ting, 2019). In 1988, an Office of the Commissioner for Administrative Complaints was created to investigate and report on complaints lodged against public organizations (So, 1995). The agency was later renamed 'Office of the Ombudsman' and it provides citizens with "a means through which an independent person outside the civil service can investigate and report on grievances arising from administrative decisions, acts, recommendations or omissions" (Hong Kong Government, 1998, p. 22). It was expected "to redress grievances arising from maladministration in the public sector through independent and impartial investigations to improve the standard of public administration" (Hong Kong Government, 2010, p. 27). The Efficiency Unit was created in 1992 to facilitate the enhancement of efficiency, economy and effectiveness. It "provides internal management consultancy services to government agencies intending to improve the quality and value of public services" and "helps to develop new service models and the application of design thinking for more engaging and effective public services" (Hong Kong Government, 2014).

In this way, the civil service in Hong Kong has been reformed by piecemeal and incremental efforts. Despite attempts to make the civil service accountable and responsive, the structure remained monolithic but simple, and the power has not shifted from the highest office, that of the Chief Executive. New agencies such as the Ombudsman, Consumer Council and Efficiency Unit were set up to reflect changes in line with other parts of the world. However, the guiding philosophy and orientation of the civil service remained unchanged. 
After establishing the underlying mechanisms for ethics and integrity in the public service and responsiveness to the citizens' needs, the next round of reforms in the civil service of Hong Kong concentrated on the improvement of financial management and service delivery. Regular and systematic reviews of public expenditures, a proper system of policy and resource management and precise definitions and delegation of responsibility for policy implementation were emphasised. The initiatives included the establishment of selfaccounting trading funds, rationalisation of public corporations and non-departmental public bodies, devolution of resource-management responsibilities, emphasis on the policy management functions of central policy branches, procedural and structural changes within the civil service to promote awareness of costs and results, and transformation of civil servants from administrators into managers (Finance Branch, 1989). However, these reforms cannot be considered as comprehensive since they focused only on financial management in the public sector (Cheung, 1992, pp. 141-142). This period also witnessed efforts to prepare comprehensive plans to ensure social welfare services because "societies have an obligation to assist their members to overcome personal and social problems and to fulfil their role in life to the optimum extent in accordance with the particular social and cultural development of their society" (Hong Kong Government, 1995, p. 3). Thus, the approach to civil service reforms changed from 'ruling' in the 1970s to 'administering' in the 1980s to 'governing' in the 1990s to reflect the gradual transition toward governance (Huque, 2002, pp. 14-15).

Reforms in the Hong Kong civil service were carefully planned with specific objectives in mind. Earlier, the objective of the government was to keep public expenditure under control, prepare and implement a balanced budget, ensure the maintenance of law and order, and get the voluntary sector to participate in the delivery of public services, wherever possible (Scott, 1986, p. 455). The distinctive features of Hong Kong were "minimal government, deference to authority, formality in administrative practice, and a high degree of centralization" that did not allow scope for deviance from rules and regulations (Lee and Huque, 1996, p. 14).

Civil service reforms in the 1990s were more radical in nature and strongly influenced by the tenets of NPM. The Civil Service Bureau released a document titled the Civil Service in the $21^{\text {st }}$ Century in 1999, which sought to "align Hong Kong with public sector developments elsewhere in the world" (Common, 1999, p. 37). "Poor health of the economy, unemployment, rising expectations of the public from the government, and the inefficient handling of several events after 1997 provided the impetus to review the administrative system" (Civil Service Bureau, 1999, p. 5). The purpose was to develop an open, flexible, equitable and structured civil service framework, an enabling and motivating environment for civil servants and a proactive, accountable and responsible culture (Huque, 2002, p. 13). However, the change of regime with the reintegration with China was followed by budget deficits and economic recession and demonstrated the importance of traditional civil service value of fiscal prudence (Burns and Wei, 2015, p. 541).

Subsequent civil service reforms in Hong Kong aimed to streamline public management through maintenance of a lean and efficient civil service, review of pay and benefits, improvement of the 'entry' and 'exit' system, provision of diversified training for public officials, and reinforcement of performance and ethical conduct. These steps were considered essential for developing and maintaining a public service that would spearhead the process of effecting improvements in the system through responsible, responsive and ethical management. Besides, the Civil Service Bureau and the Independent Commission Against Corruption introduced a joint ethical leadership program that is intended to instil a culture of probity in the civil service (Hong Kong Government, 2010, p. 26). Thus, civil service reforms in Hong Kong have targeted at increased economy and efficiency with concessions on citizen involvement and emphasis on ethics to demonstrate sensitivity to the changes in the society.

To sum up, the key themes of civil service reforms included structural changes to restore trust in the government by opening channels of communication between the government and
Civil service reforms in Hong Kong and Thailand 
PAP

23,2

citizens. Effective anti-corruption measures and a redress mechanism sought to facilitate public participation. Reforms aimed to ensure prudent financial management and the attainment of economy, efficiency and effectiveness through agencification, market-testing and corporatization. Eventually, public-private partnerships and performance-based budgeting were adopted as well as the enhancement of integrity and ethics in the civil service.

\section{6}

\section{Civil service reforms in Thailand}

Thailand has a much longer history of civil service reforms. The first Civil Service Act of 1928 introduced a merit system based on competence, equity, security, and political neutrality (OCSC, 1993). A change from absolute monarchy to democracy in 1932 shifted power from the royal family to the bureaucrats, including the military officers. From 1932 to the early 1970s, administrative power was mainly in the hands of military dictators who preferred to have authority centralized. The roles of the bureaucrats and politicians could hardly be differentiated during this period, as most politicians had backgrounds as high-ranked officers in the ministries and/or the military. The bureaucracy was strong and the political system unstable, and this enabled the civil servants to resist reforms and only minor adjustments were made to the existing structure and practices (Painter, 2004).

During the 1970s, a movement for democracy and confrontation between the citizens and the military resulted in civil unrest. Bowornwathana (2013) pointed out that improving bureaucratic performance became a secondary goal when the regime was unstable and bureaucrats continued to exercise power. The political situation stabilised in the 1980s. During this period, elected governments were concerned about improving service provision to citizens that had not featured in the earlier reforms. Several reforms were introduced such as anti-corruption practices, efficiency enhancement, service delivery, private sector involvement, budgeting, and compensation of public officials (Worragi, 2003). This trend was influenced by global reform trends that aimed to enhance the performance and quality of civil service throughout the 1980s.

In the 1990s, the focus of reforms remained on, among other areas, service delivery improvement, equity in accessing public services, and public participation (Worragi, 2003). The Third Civil Service Act of 1992 concentrated on the democratic, managerial and strategic elements. This Act highlighted the importance of encouraging performance through compensation and rewards (Sivaraks, 2011). The Eighth National Economic and Social Development Plan (1997-2001) guided the direction of reforms in the late 1990s. The Plan included strategies of administrative downsizing and reorganization; shifting the role of government from controlling to facilitating; improving administrative systems at the central administration; decentralizing decision-making authority to lower levels of administration; and a more flexible budgeting system (Painter, 2006). The prominent influence of NPM was evident in this round of reform.

A democratic constitution for Thailand was promulgated in 1997, and it had a strong influence on civil service reforms in the late 1990s. The Constitution promoted democratic governance practices such as accountability, integrity, citizen empowerment, and decentralisation. The role of the central government was hollowed and there were attempts to downsize through early retirement schemes (Painter, 2006). Decentralisation of functions and budget to local governments received prominent attention in this Constitution (Jongruck, 2014).

The financial crisis in 1997 encouraged, if not mandated, the incorporation of good governance principles into the Thai public sector (The World Bank, 2003; Bowornwathana, 2005). Seven elements of good governance were identified to maximise benefits for citizens: achieving public goals; emphasizing efficiency and value for money; streamlining work processes; reviewing periodically to ensure relevance; satisfying citizens' demands; and monitoring and evaluating performance (OPDC, 2018a). A number of autonomous public 
organizations and independent watchdogs, such as a Constitutional court, anti-corruption commission, and audit commission, were established (Worragi, 2003).

The political situation in Thailand was stable after Thaksin Shinawatra won a landslide victory in the 2001 and 2005 elections. Several radical civil service reforms were introduced during this period. The managerial reform rhetoric was prominent, and the government attempted a shake-up of bureaucratic structures and positions through a political process (Painter, 2004). Some major reform programs included, for instance, ministry restructuring, performance-based management, and the CEO-provincial governor.

The restructuring of the central ministries was a radical reform; however, it did not apply to lower levels of the government. Interestingly, the number of ministries and departments was increased from 14 to 20 in 2002 (Painter, 2006). Bowornwathana (2013) noted the common practice of democratic government in Thailand to establish a larger number of administrative domains to create new cabinet positions. A performance-based approach was introduced for personnel management and budgeting. Nevertheless, the performance evaluation system was, by and large, ineffective because of the lack of reliable information on performance output and outcomes (The World Bank, 2003). Another reform was the empowerment of the provincial governors who were designated as "CEO-provincial governors". The CEOgovernors report directly to the Prime Minister and the arrangement helped concentrate administrative power in the hands of the political executives. During this rare occasion, when Thailand experienced strong political stability, the autonomous bureaucracy experienced high intervention from politicians and became subjected to political control (Bowornwathana, 2005; Painter, 2006).

Civil service reforms received little attention during 2006-2013 due to political unrest. Some significant reforms during this period were the enactment of the 2008 Civil Service Act and the introduction of a new classification system which identified four types of positions in the civil service, namely: executive, managerial, knowledge worker, and general positions. Additionally, the government launched a minimum pay reform for civil servants in 2013 by raising the minimum monthly salary to 15,000 Baht (approximately US $\$ 420$ ) to boost the morale of government officials and to attract new graduates to work in the public sector (TDRI, 2014).

Thailand experienced another coup in 2014, and the military government ruled the country until 2019. Reforms during this period limited the role of politicians and strengthened the position of the civil servants and military officers. A 20-Year National Strategy (2017-2036) was introduced in 2017, and all governmental agencies were mandated by the Constitution to follow the plan. The Office of the Civil Service Commission (OCSC) has accordingly launched a Strategic Plan of Human Resource Management for government agencies (2017-2036). The plan aims to respond to the needs of citizens in terms of effectiveness, efficiency, worthiness, transparency, fairness and adaptability to current social and economic changes (OCSC, 2019b). It is evident that good governance principles have persisted in the civil service reform preference in Thailand over the past decade. The government also launched the 'Thailand 4.0' scheme to shift the country's economy to a technological and innovation-driven system. The 'Government 4.0' is a response to the Thailand 4.0 scheme, which aims to make service delivery easier, cheaper, faster, and smarter. The government innovation lab, participatory governance, and Good Governance 4.0 are also parts of the Government 4.0 reforms (OPDC, 2018b). The latest wave of civil service reforms in Thailand clearly focuses on modernizing the bureaucracy with innovation and technology.

In summary, the role of the civil service has been dominant in Thailand since its establishment and has become stronger over time as political instability persisted. Most of the reforms before the 1980s were piecemeal and incremental in nature. Attempts to improve service delivery have always been included in the reform agenda. At the same time, the managerial approach was adopted in the 1990s because of the influence of the global NPM-
Civil service reforms in Hong Kong and Thailand 
PAP

23,2

118

driven trend, although the strategy of downsizing was not apparent in Thailand. Following the financial crisis in 1997, Thailand adopted the good governance agenda for public sector reforms, and this meant increased attention to the values of participation, accountability and integrity. Civil service reforms tended to be radical under a strong political executive, but the bureaucracy gained the upper hand during periods of political unrest. This suggests that civil service reforms in Thailand were largely dependent on the political will of the regime. Although there have been several attempts to modernize the civil service system, the results of the reforms remain unclear.

\section{Outcome and impact of civil service reforms in Hong Kong and Thailand}

Civil service reforms in Hong Kong shifted from tinkering with structures and arrangements to an approach of inculcating a new set of values and orientation, with emphasis on accountability, economy, efficiency and performance. The government claimed that the Enhanced Productivity Programme helped reduce costs through reorganization of structures, redistribution of duties, an adjustment in levels of service in line with demands and utilisation, use of contracting-out, and saving on allowances (Hong Kong Government, 2002). The civil service establishment was streamlined through a review of pay and benefits, improvement of the system of entering and leaving service, diversification of training and reinforcement of performance and proper conduct (Civil Service Bureau, 1999). These were basically efficiency-oriented measures in the sense that the same or higher amount of work and service was expected from the efforts of fewer civil servants. The number of employees was reduced through re-engineering of processes, organizational review, outsourcing and voluntary retirement (Huque, 2010, p. 278).

Cheung (1999) criticized the idea of following the private sector practice in measuring and rewarding performance. Perry and Frederickson were, however, optimistic about the success of reforms only if they "were implemented with careful attention" (1999, p. 68). Thus, the analysts were concerned over the assumptions, rationale and operational issues of reforms (Huque, 2002, p. 16). Nevertheless, streamlined rules on the award or stoppage/deferment of salary increments were intended to elicit the best performance from civil servants. The stated objective of the government was to "provide the necessary flexibility and capability to allow the Civil Service to respond quickly to community needs; to provide a more motivating and positive work environment; and to further a performance-based service-oriented management culture" (Civil Service Bureau, 2009). Despite claims for aiming for broadbased governance values, the emphasis remained on enhancing efficiency and maintaining competitiveness.

The major reforms in Thailand can be categorized in terms of structural, managerial, and good governance objectives. In terms of structural reform, the outcome in Thailand did not result in the downsizing of the public sector. The Thailand Future Foundation (TFF) reported that the civil service had become larger after the structural reform in 2001, and the number of departments and offices increased from 168 in 2002 to 181 in 2015. The total number of government officials grew by 50 percent from 2004, from approximately 1.5 million to nearly 2.2 million in 2014 (TFF, 2015). The size of the civil service remains almost at the same level as in 2018 (OCSC, 2019a). Although the number of long-tenured civil servants (kha-raja-garn) was reduced, a much more significant increase can be found among other types of government officials, such as state employees.

The increasing number of state employees added to the financial burden of the country. Expenditure on personnel increased dramatically after the minimum pay reform in 2013 that enhanced the salary of government officials to make their compensation higher than that in the private sector (TFF, 2015). Despite several attempts to reform the civil service over the past four decades, there is little evidence of success. 
There are interesting parallels and contrasts between civil service reforms in Hong Kong and Thailand. Following the global trend, most countries jumped on the NPM bandwagon, and Hong Kong and Thailand were no exception. Earlier, some common problems affected public administration and resulted in the concentration of power in huge bureaucracies, lack of transparency and accountability, rigid and unresponsive approach, and scant regard for the cost that contributed to the loss of trust in governments. The responses were manifested in a series of reforms in the two cases.

The status of Hong Kong as a British territory before 1997 and a Special Administrative Region of China afterwards have produced a unique context for introducing civil service reforms. While reforms are generally proposed, designed and adopted under political leadership in most countries with approval from the legislature, Hong Kong followed a different route. It is described as an "administrative state" that possesses legislative and judicial organs, but in which administrative organization and operations are prominent" (Harris, 1988, p. 70). In the absence of a political elite and fully elected legislature, proposals for civil service reforms were prepared by the Civil Service Bureau and endorsed by the government. In other words, the bureaucracy decided on the nature and direction of reforms and, understandably, the interest of the civil servants remained protected.

Similarities in terms of power exercised by the bureaucracy can be identified between the "bureaucratic polity" of Thailand (Riggs, 1966) and the "administrative state" of Hong Kong (Harris, 1988). NPM principles were the driving force in both cases, and Hong Kong was able to implement them effectively due to the tradition of colonial style of administration, the small size of the territory, an efficient and powerful bureaucracy, and lack of a normal political system for providing checks and balances. On the other hand, the tradition of administration in a kingdom, combined with starkly different societal and political dynamics allowed Thailand to adopt these principles only at a rhetoric level. The market-oriented approach was more easily adopted to enhance efficiency and productivity in Hong Kong, while the managerial label was used for political purposes to centralize power and control by the bureaucracy in Thailand.

The managerial approach appeared to be suitable for Hong Kong because it has had a history of a hierarchical and centralized system of public sector management. The territory was built on the hard work of inhabitants who are committed to efficiency, adherence to the rule of law and obedience to authority. The crisis of governance and political legitimacy in Hong Kong after its reintegration with China made the government scramble for performance legitimacy and that could only be attained with higher efficiency in the civil service. The problem of legitimacy added to the complexity of designing and sustaining civil service reforms. Moreover, Hong Kong was hit by a series of problems initiated by bird flu, the Asian economic crisis, and other issues (Huque and Lee, 2018). These incidences revealed weaknesses in the existing arrangements for management in the public sector, but it was left to the bureaucracy to determine strategies for dealing with them.

Thailand, too, encountered several challenges after the economic crisis of 1997. While Hong Kong preferred to employ the managerial approach to deal with emergencies, Thailand was encouraged by international organizations to incorporate good governance principles in its reforms. However, no radical change resulted in practice apart from the promulgation of some legislation on good governance. In short, civil service reforms in Thailand were superficially guided by a combination of NPM and good governance strategies.

Apparently, reforms in Hong Kong were intended to enhance efficiency, reduce expenditure, improve the quality of public service and bring the civil service in line with the demands of the contemporary world. They also reflected the changing relationships between the government and society as Hong Kong constructed the base for a strong economy, expanded social services and faced increased demands for participation. Pressure from the international community to conform to standards of environmental protection,
Civil service reforms in Hong Kong and Thailand 
human and intellectual property rights, and trade and commerce practices prompted further adjustments in the civil service. Changing mood in the territory, the undercurrent of democratization and increasing public awareness opened up opportunities for a push toward good governance, and the civil service was expected to become more responsive to the needs of the citizens who would have an opportunity to participate in public affairs (Huque, 2010, p. 280).

While the outcome of reforms may be considered moderately successful in the case of Hong Kong in terms of better service delivery, the case of Thailand seems to have contradictory results. Reform attempts over the past four decades have resulted in the expansion of the public sector, declining performance, and the problem of corruption persists. The contrast points to the relevance of traditions and capacity of governments, and also raises questions about the relative importance of management and governance principles in civil service reforms.

\section{Conclusion}

A comparison of civil service reforms in Hong Kong and Thailand suggests that there is no single path to successful reforms. Although the two units have dissimilar historical backgrounds and political systems, the expected outcomes of planned reforms were closely aligned with global trends of NPM and good governance. Understandably, they were keen on downsizing governments, reducing public expenditure, and instituting a performance-based culture to overcome the problems encountered in the traditional model of civil service. In addition, reform efforts sought to emphasize merit, accountability, transparency, public participation and empowerment. Therefore, there were common objectives and similar goals were included in the reform designs. However, the values held by the regimes in power led to the adoption of different strategies for civil service reforms in Hong Kong and Thailand.

Civil service reforms in Hong Kong focused mainly on management by applying strategies of streamlining procedures, restructuring organizations, and strengthening financial management to ensure economy and efficiency. But in the case of Thailand, governance values such as integrity, capacity, transparency and accountability emerged as preferred targets and therefore the reform approaches were different. Over this period, Hong Kong prepared to depart from its colonial status and establish the city as a special administrative region of China, while Thailand struggled to overcome the problem of intermittent military takeovers.

Civil service reforms in Hong Kong could be accomplished at lower risks because the number of civil servants was small, and the government was able to exercise control over the process. It was easier to follow the NPM prescriptions as there was no conflict with the regime values. In Thailand, it was a much more ambitious and complex undertaking with a huge bureaucracy operating at several levels. Governing the country entailed appreciation of diverse needs of different groups. This called for adjustments to existing civil service structures and relationships while maintaining the advantages of its economic progress.

Hong Kong was strongly influenced by the British reform approach and embraced principles following its introduction in the United Kingdom. It was relatively successful because the changes were conceived and designed by the Civil Service Bureau after limited consultation with the public and members of the Legislative Council. The bureaucracy played a dominant role in the process and helped implement them without resistance. On the other hand, reforms in Thailand were influenced by diverse forces and, on occasions, there was a confrontation between the bureaucracy and political elite as well as citizens. While the international trend and pressures could not be resisted entirely in Thailand, indigenous conditions posed substantial obstacles to radical changes. The directions of reforms were usually determined by senior bureaucrats who preferred to mimic efforts in Western developed countries. Consequently, the reforms could not be planned with a united vision and turned out to be rhetorical in nature. Finally, Hong Kong and Thailand chose to take different 
paths to arrive at the same ends, but social, economic and political circumstances led them to different outcomes.

\section{References}

Bowornwathana, B. (2001), "Thailand: bureaucracy under coalition governments", in Burns, J.P. and Bowornwathana, B. (Eds.), Civil Service Systems in Asia, Edward Elgar, Cheltenham, pp. 281-318.

Bowornwathana, B. (2005), "Administrative reform and tidal waves from regime shifts: tsunamis in Thailand's political and administrative history", Asia Pacific Journal of Public Administration, Vol. 27 No. 1, pp. 37-52.

Bowornwathana, B. (2013), "Administrative reform and regime shifts: reflections on the Thai polity", Asia Pacific Journal of Public Administration, Vol. 35 No. 2, pp. 137-147.

Bowornwathana, B. and Poocharoen, O. (2005), "Managing reforms: the politics of organizing reform work", Public Organization Review, Vol. 5 No. 3, pp. 233-247.

Brinkerhoff, D.W. and Brinkerhoff, J.M. (2015), "Public sector management reform in developing countries: perspectives beyond NPM orthodoxy", Public Administration and Development, Vol. 35 No. 4, pp. 222-237.

Brown, I. (1992), The Creation of the Modern Ministry of Finance in Siam, 1885-1910, Macmillan, Basingstoke.

Burns, J. and Wei, L. (2015), "The impact of external change on civil service values in post-colonial Hong Kong”, The China Quarterly, Vol. 222, pp. 522-546.

Cheung, A.B.L. (1992), "Public sector reform in Hong Kong: perspectives and problems", Asian Journal of Public Administration, Vol. 14 No. 2, pp. 115-148.

Cheung, A.B.L. (1999), "Moving into performance pay for Hong Kong civil servants: conceptualization and implementation problems", Public Administration and Policy, Vol. 8 No. 2, pp. 9-22.

Cheung, A.B.L. (2011), "NPM in Asian countries", in Christensen, T. and Laegreid, P. (Eds.), The Ashgate Research Companion to New Public Management, Ashgate, Farnham, pp. 131-146.

Civil Service Bureau (1999), Civil Service into the $21^{\text {st }}$ Century: Civil Service Reform Consultation Document, Civil Service Bureau, Hong Kong.

Civil Service Bureau (2009), “Civil Service Reform”, available at: http://www.csb.gov.hk/english/csr/9. html (accessed 15 April 2020).

Common, R. (1999), "Civil Service Reform in Hong Kong: conforming to the global trend?", Public Administration and Policy, Vol. 8 No. 2, pp. 37-56.

de Vries, M. and Nemec, J. (2013), "Public sector reform: an overview of recent literature and research on NPM and alternative paths", International Journal of Public Sector Management, Vol. 26 No. 1, pp. 4-16, doi: 10.1108/09513551311293408.

England, J. and Rear, J. (1981), Industrial Relations and Law in Hong Kong: An Extensively Rewritten Version of Chinese Labour under British Rule, Oxford University Press, Hong Kong.

Finance Branch (1989), Public Sector Reform, Hong Kong Government, Hong Kong.

Grindle, M.S. (2017), "Good governance, R.I.P.: a critique and an alternative”, Governance, Vol. 30 No. 1, pp. 17-22.

Harris, P. (1988), Hong Kong: A Study in Bureaucracy and Politics, Macmillan, Hong Kong.

Hong Kong Government (1995), The Five Year Plan for Social Welfare Development in Hong Kong - Review 1995, Government Printer, Hong Kong.

Hong Kong Government (1996), Hong Kong 1996, Government Information Services, Hong Kong.

Hong Kong Government (1998), Hong Kong 1998, Government Information Services, Hong Kong.

Hong Kong Government (2002), "Enhanced Productivity Programme: 2001-02 Booklet", available at: https://www.fstb.gov.hk/tb/en/epp-booklet-2001-2002.htm (accessed 10 February 2020).
Civil service reforms in Hong Kong and Thailand 
PAP

23,2

Hong Kong Government (2010), “The Budget 2010-11”, available at: https:/www.budget.gov.hk/2010/ eng/pdf/BudgetSpeech2010-11_e.pdf (accessed 12 March 2020).

Hong Kong Government (2014), Hong Kong Yearbook, Information Services Department, Hong Kong.

Hong Kong Government (2018), Hong Kong Yearbook, Information Services Department, Hong Kong.

Hughes, O. (2012), Public Management and Administration: An Introduction, $4^{\text {th }}$ edition, Macmillan, Basingstoke.

Huque, A.S. (1990), Paradoxes in Public Administration: Dimensions of Development, University Press, Dhaka.

Huque, A.S. (2002), "Government-society relations and the politics of administrative reform in Hong Kong", Public Policy and Administration, Vol. 17 No. 1, pp. 5-20.

Huque, A.S. (2010), "Managing the public sector in Hong Kong: trends and adjustments", Asian Journal of Political Science, Vol. 18 No. 3, pp. 269-288.

Huque, A.S. and Lee, G. (2018), Managing Public Services: Crises and Lessons from Hong Kong, Routledge, London.

Huque, A.S., Lee, G. and Cheung, A.B.L. (1998), The Civil Service in Hong Kong, Hong Kong University Press, Hong Kong.

Jongruck, P. (2014), "Paradoxes of decentralization in Thailand: evidence from decentralizing the task of controlling illegal drugs to local governments", in Conteh, C. and Huque, A.S. (Eds.), Public Sector Reforms in Developing Countries: Paradoxes and Practices, Routledge, London and New York, NY, pp. 95-105.

Lee, G. and Huque, A.S. (1996), "Hong Kong: administrative reform and recent public sector changes the institutionalisation of new values", Australian Journal of Public Administration, Vol. 16 No. 2, pp. 1-16.

Office of the Civil Service Commission (OCSC) (1993), King Prajadhipok and the Civil Service System, Office of Civil Service Commission, Bangkok (in Thai).

Office of the Civil Service Commission (OCSC) (2019a), "Public sector workforce in civil service 2018", available at: https://www.ocsc.go.th/sites/default/files/document/9786165482066-thai-govmanpower-2561.pdf (in Thai) (accessed 1 March 2020).

Office of the Civil Service Commission (OCSC) (2019b), "Operational plan for creating and enhancing the strategic human resource management for Digital Thailand", available at: https://www.ocsc. go.th/digital_hr (in Thai) (accessed 1 March 2020).

Office of the Public Sector Development Commission (OPDC) (2018a), "15 years of OPDC, 15 years of public sector development”, available at: https://www.opdc.go.th/content/viewbook/ MTA4OXx8Mnx8dGh8fHgyN0kz\#book/ (in Thai) (accessed 2 April 2020).

Office of the Public Sector Development Commission (OPDC) (2018b), "Government 4.0: Time to transform”, available at: https://www.parliament.go.th/ewtadmin/ewt/parliament_parcy/ewt_ dl_link.php?nid=42879 (accessed 2 April 2020).

Painter, M. (2004), "The politics of administrative reform in East and Southeast Asia: from gridlock to continuous self-improvement?", Governance, Vol. 17 No. 3, pp. 361-386.

Painter, M. (2006), "Thaksinisation or managerialism? Reforming the Thai bureaucracy”, Journal of Contemporary Asia, Vol. 36 No. 1, pp. 26-47.

Perry, J. and Frederickson, D. (1999), "Hong Kong's civil service reform: lessons learned from the American experience", Public Administration and Policy, Vol. 8 No. 2, pp. 57-70.

Repucci, S. (2014), "Designing effective civil service reform: lessons from past experience", Public Administration and Development, Vol. 34 No. 3, pp. 207-218.

Rhodes, R.A.W. (2016), "Recovering the craft of public administration", Public Administration Review, Vol. 76 No. 4, pp. 638-647.

Riggs, F. (1966), Thailand: The Modernization of a Bureaucratic Polity, East-West Center Press, Honolulu. 
Scott, I. (1984), "Introduction," in Scott, I. and Burns, J.P. (Eds.), The Hong Kong Civil Service: Personnel Policies and Practices, Oxford University Press, Hong Kong, pp. 1-16.

Scott, I. (1986), "Policy-making in a turbulent environment: the case of Hong Kong", International Review of Administrative Sciences, Vol. 52 No. 1, pp. 447-469.

Scott, I. and Ting, G. (2019), Corruption Prevention and Governance in Hong Kong, Routledge, London.

Sivaraks, P. (2011), "Civil service system in Thailand", in Berman, E.M. (Ed.), Public Administration in Southeast Asia: Thailand, Philippines, Malaysia, Hong Kong, and Macao, CRC Press, Boca Raton, pp. 113-137.

So, K.W. (1995), "Bringing COMAC to people", Hong Kong Public Administration, Vol. 4 No. 1, pp. $145-152$.

Thailand Development Research Institute (TDRI) (2014), "Economic impact from the 300 baht minimum wage policy and 15,000 baht salary for Bachelor's degree graduates", available at: https://tri.or.th/wp-content/uploads/2014/04/wb101.pdf (in Thai) (accessed 4 August 2020).

Thailand Future Foundation (TFF) (2015), "10 years facts of Thai civil servants", available at: https:// bit.ly/3mxfICn (in Thai) (accessed 4 March 2020).

The World Bank (2003), Thailand Country Development Partnership: Governance and Public Sector Reform (Phase I), The World Bank, Bangkok and Washington, DC.

Tjiptoherijanto, P. (2018), "Between two cultures: civil service reform in Thailand and Indonesia", Chinese Business Review, Vol. 17 No. 6, pp. 279-286.

United Nations Development Programme (UNDP) (1997), Governance for Sustainable Human Development: A UNDP Policy Document, United Nations Development Programme, New York, NY.

Worragi, A. (2003), "Public sector reform: moving forward or backward", King Prajadipok's Institute Journal, Vol. 2003 No. 2, pp. 7-37.

\section{About the authors}

Ahmed Shafiqul Huque, $\mathrm{PhD}$ (University of British Columbia), is a Professor in the Department of Political Science at McMaster University, Canada. His research interests are in the areas of governance, public policy and administration, and development. Prof. Huque is the co-author/co-editor of several books including The Civil Service in Hong Kong (Hong Kong University Press), Managing Development in a Globalized World (CRC Press), International Development Governance (CRC Press), Public Administration in the NICs (Macmillan), and Social Policy in Hong Kong (Edward Elgar).

Patamawadee Jongruck, PhD (University of Manchester), is an Assistant Professor of Public Administration in the Faculty of Political Science and Public Administration at Chiang Mai University, Thailand. She conducted research at the Institute for Development Policy and Management (IDPM) at the University of Manchester, UK. Dr. Jongruck's research interests are in the areas of public sector reform, network governance, good governance, decentralization, and illicit drugs control policy in developing countries, and Thailand in particular. She has presented papers at a number of international and national conferences. Patamawadee Jongruck is the corresponding author and can be contacted at: patamawadee.j@cmu.ac.th
Civil service reforms in Hong Kong and Thailand 